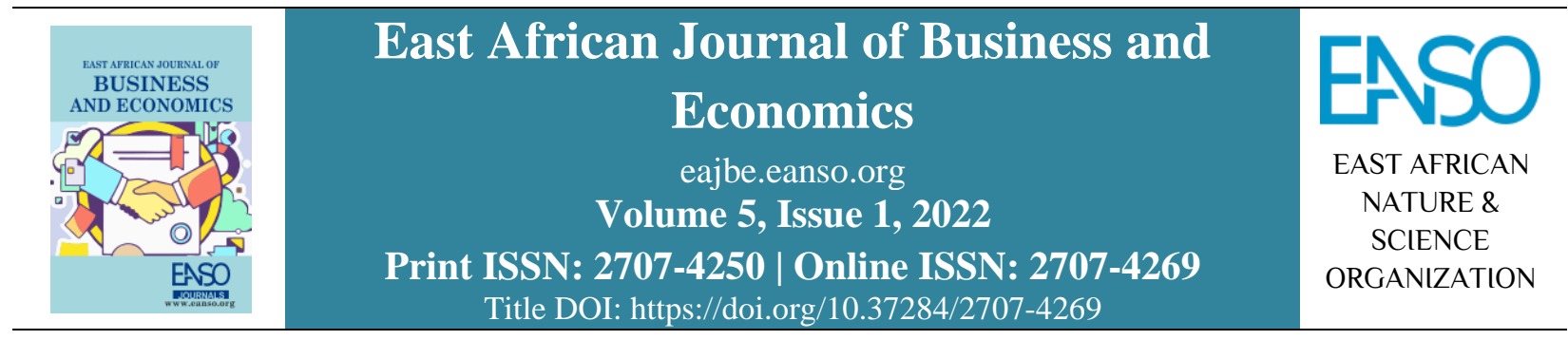

Original Article

\title{
Flexible Work Arrangement and Employee Performance: An Evidence of Work-life Balance Practices.
}

\author{
Festus Bett ${ }^{1 *}$, Dr. Hellen Sang, PhD ${ }^{1}$, Dr. Patricia Chepkwony, PhD ${ }^{1}$ \\ ${ }^{1}$ University of Kabianga. P. O. Box 2030-20200, Kericho, Kenya. \\ * ORCID: https://orcid.org/0000-0001-8724-5964; Correspondence email: festusbett@ gmail.com.
}

Article DOI: https://doi.org/10.37284/eajbe.5.1.557

\section{Date Published: ABSTRACT}

22 February 2022 Work-life balance is basically the positive relationship between work and other equally important activities in life which include family, leisure, personal

Keywords: development, and community development issues. The relationship cannot be clearly defined and varies from person to person according to their life demands.

Flexible Work Work-life balance is intended to allow employees greater flexibility in their Arrangement, working patterns so that they can balance what they do at work with the Employee responsibilities and interests they have outside work. This study sought to assess Performance, operatives in Kericho County. The study was anchored on spillover theory. A Correlation correlational research design was adopted. The target population of the study was Design, all the employees working in agricultural co-operatives in Kericho County, who Kenya. are 210 employees and a sample size of 137 respondents. The study utilised primary data collected using both structured and unstructured questionnaires. The study use means and standard deviation as descriptive analysis. Correlation analysis was used to test the hypothesis and the relationship between the study variables. The study found that flexible work arrangement was achieved through employee reorganisation, schedule and development shifts. This reduced absenteeism, expanded the number of hours of giving out service and enabled employees to seek new roles. The results revealed a significant positive relationship between flexible work arrangements and employee performance $(\mathrm{R}=$ $0.801, \mathrm{p}<0.05)$. The study concluded that the flexible work arrangement and teleworking had a significant positive effect on employee performance. The study recommended that the Agricultural societies should improve flexible work arrangements through the adoption of ICT infrastructure.

\section{APA CITATION}

Bett, F., Sang, H., \& Chepkwony, P. (2022). Flexible Work Arrangement and Employee Performance: An Evidence of Worklife Balance Practices. East African Journal of Business and Economics, 5(1), 80-89. https://doi.org/10.37284/eajbe.5.1.557. 


\section{CHICAGO CITATION}

Bett, Festus, Hellen Sang, and Patricia Chepkwony. 2022. "Flexible Work Arrangement and Employee Performance: An Evidence of Work-life Balance Practices". East African Journal of Business and Economics 5 (1), 80-89. https://doi.org/10.37284/eajbe.5.1.557.

\section{HARVARD CITATION}

Bett, F., Sang, H., \& Chepkwony, W. (2022) "Flexible Work Arrangement and Employee Performance: An Evidence of Worklife Balance Practices", East African Journal of Business and Economics, 5(1), pp. 80-89. doi: 10.37284/eajbe.5.1.557.

\section{IEEE CITATION}

F. Bett, H. Sang, \& W. Chepkwony, "Flexible Work Arrangement and Employee Performance: An Evidence of Work-life Balance Practices", EAJBE, vol. 5, no. 1, pp. 80-89, Feb. 2022.

\section{MLA CITATION}

Bett, Festus, Hellen Sang, and Patricia Chepkwony. "Flexible Work Arrangement and Employee Performance: An Evidence of Work-life Balance Practices". East African Journal of Business and Economics, Vol. 5, no. 1, Feb. 2022, pp. 80-89, doi:10.37284/eajbe.5.1.557.

\section{INTRODUCTION}

Work-life balance involves the modification of work arrangements so as to allow workers to amalgamate work responsibilities and family tasks. Satisfying a healthy work-life balance is a matter which has increased recognition being strategic and important to the organisations since the hours at which an individual employee is scheduled to work and work-life balance affects their mental, health, physical and well-being (Mendis \& Weerakkody, 2014). Work-life balance therefore comprises components such as flexible work arrangements which allow workers to execute other life programs and practices. It is the terminology universally applied while relating to the balance of an individual working needs between time allocated for work and other aspects of life such as family interest, social and leisure (Wilkinson et al., 2018).

Dousin et al. (2019) in Malaysia examined the impact of work-life on the performance of employees using doctors and nurses as a case study. It was found out that flexible working hours and supervision that is supportive positively and significantly influences employee job performance. Job satisfaction significantly became an intervening variable in the relationship that existed between the flexible working hours and supportive supervision on employees' performance. Effective work-life equilibrium support employees' contentment which eventually increases the employee job performance and their productivity. The healthcare sector benefited from the findings of this study and led to increased employee attraction, retention and motivation which have led to increased employee productivity.

A study conducted by Kasau (2017) pointed out that work arrangement positively related to the performance of employees. The study therefore suggested that employees be given a work environment that is more flexible provided it would not lead to reduced organisational performance and improvement of welfare services like childcare, recreational facilities, and counselling. Mulanya and Kagiri (2018) also examined the work-life equilibrium and employee's performance in Constitutional Commission in Kenya. The absence of a flexible work schedule reduces employee motivation hence low performance. It was also found out that the commission is not engaging in encouraging employee job sharing and every employee was only performing his assigned task. Employee breaks were found to positively and significantly influence the performance of the employees. Whenever an employee goes for his/her annual, paid leave, they resume work when they feel re-energised, and the performance is higher than those who had not gone for their leaves.

Employees in the agricultural co-operatives in Kenya have been more involved in their occupations, working more than the standard hours 
(8 hours) set by the international labour organisation (ILO, 2010). This has made it difficult for employees to maintain a balance between work, life, and individual issues while the counterparts in other sectors have been spending fewer hours working (Talukder, 2019). Moreover, the agricultural cooperatives have been agreed as the most affected sector by work-life imbalance and were ranked by ILO (2010) sixth in the list of 24 industries under observations. Employee satisfaction is closely related to balancing organisation tasks and life. Despite the noteworthy benefits that accrue from employee work-life balance, agricultural cooperatives in Kericho County have not been in a position to facilitate their workers balance between work and life to improve the benefits. The relationship between work-life balance and employees' productivity in agricultural cooperatives has not been explored and remains a grey area for the studies. Therefore, the objective of the study was to determine the relationship between flexible work arrangements and employee performance in agricultural co-operatives in Kericho County.

\section{LITERATURE REVIEW}

\section{Theoretical Literature}

The spillover was first proposed by Frischman and Lemley (2007). The theory assesses the relationship that exists between the work domain and the home environment. This happens when the conversion of emotions related to work are transferred to family members at home. The theory proposes that what takes place where one works and where he or she lives to share some similarities (Sidin et al., 2010). The spillover theory informs employee performance of the agricultural sector to consider flexible working arrangements to reduce the spillover effect of stress to home environments. Since there is a possibility of a positive spillover in terms of high performance of the co-operative and vice versa.

\section{Flexible Working Arrangements and Employee Performance}

Felstead and Henseke (2017) conducted in the Netherlands on the effects of time-spatial flexibility and new working environment on employees' worklife balance. The study investigated the time spatial equilibrium amid employees and family time. It was concluded that the time spatial flexibility did not have a significant impact on workers' conditions. Flexible working arrangements can be explained as a scenario where an employee is allowed to work in particular place at a given time to meet their work target and deliver their duties as expected by employers (Karimi, 2019). Flexible arrangements create a system that is adjustable for the number of hours available and location an employee is required to work for both part-time and non-part time workers in an organisation.

A study by Sánchez-Hernández et al. (2019) on workers on part-time arrangements noted that worklife balance gained much prominence in the recent past from both scholars and policymakers. Haar and Brougham (2020) conducted a study on flexible working arrangements and the performance of employees in New Zealand using a correlation research design. The study showed positive results on the flexible working arrangements and it showed that it significantly led to reduced cases of work-life balance conflict. It was contended that a representative's capacity to arrange a working course of action that permits them the laxity to manage individual and family issues eliminates pressure hence enhancing work-life equalisation and struggle. The resultant impact is improved worker execution; transient work contracts are haggled among representatives and managers. It grants workers the influence to have the option to work in both part-time work and employment circles with negligible obstructions, subsequently work fulfilment that upgrades work execution.

As indicated by Sirma (2015), temporary employment agreements as a component of 
adaptable working arrangements minimise expenses related to recruitment, orientations, and training of workers. They further contend that representative's execution is upgraded since balance in work-life is accomplished, and workers are inspired. Employees' performance can in this way, improve workers' competitive advantage and the probability of a decline in workers' deceptive practices. Lessening in exploitative practices enhances workers' promises to improve performance and profitability (Muslehand AlMaaitahn (2019).

\section{RESEARCH METHODOLOGY}

The study adopted a correlational research design in determining the relationship between flexible work arrangements and employee performance in agricultural co-operatives in Kericho County. The study targeted 76 employees of coffee cooperatives, 98 employees of dairy co-operatives and 36 employees of tea co-operatives in the County of Kericho. This research study used a sample size of 137 respondents that were randomly selected from a target population of 210 employees. Selfadministered questionnaires were used to collect data. Descriptive statistics were performed using mean and standard deviation. Inferential statistics were done using Pearson Correlation analysis.

\section{RESULTS AND DISCUSSIONS}

\section{Flexible Work Arrangement}

A flexible working arrangement was determined using descriptive statistics derived from the frequency distribution of respondents. Frequencies were based on a Likert scale where 1 is for strongly disagree to 5 is for strongly agree. Mean was calculated from the distribution where a mean of 3 and above represented agree-ability; standard deviation above 1 indicated heterogeneous opinion.

Table 1 revealed that the co-operatives offer the employees a flexible work arrangement since $53(43.8 \%)$ strongly agreed and 51(42.1\%) agreed on that statement. A mean of 4.2975 flexible work arrangement was satisfactorily adopted in the cooperative. While a standard deviation of 0.70291 revealed low variation in opinions which indicated homogeneous opinions from different agricultural co-operative. According to the results, the employees can reorganise their tasks so that they can be done satisfactorily on time $(M=4.3058)$. Where 56(46.3\%) strongly agreed, 46(38.0\%) agreed, and 19(15.7\%) respondents were not sure. There was low variation with a standard deviation of 0.72850 , which implied the opinions were similar across the agricultural co-operative.

The respondents valued the flexible working schedule more than seeking a new role in another firm $(M=4.1322)$, of which $47(38.8 \%)$ strongly agreed, $48(39.7 \%)$ agreed, 21(17.4\%) were not sure, and $5(4.1 \%)$ disagreed. However, the variation was low with a standard deviation of 0.84599 , which indicated homogeneous opinions across the respondents. $37(30.6 \%)$ respondents strongly agreed, 67(55.4\%) agreed, and 17(14.0\%) were not sure about expanding the number of hours done through the work shift. Hence their results revealed that expanding the number of hours of giving out services was done through work shift which satisfactorily influenced the number of hours an employee could perform his/her tasks $(M=4.1653)$. A standard deviation of 0.64996 showed there was low variation in opinion across the respondents 


\section{Table 1: Descriptive Statistics on Flexible Work Arrangement}

\begin{tabular}{|c|c|c|c|c|c|c|c|}
\hline & SA & $\mathbf{A}$ & $\mathbf{N}$ & D & $\mathbf{S}$ & Mean & Std Dev. \\
\hline $\begin{array}{l}\text { My Co-operative offers employees a flexible work } \\
\text { arrangement }\end{array}$ & $53(43.8 \%)$ & $51(42.1 \%)$ & $0(0.0 \%)$ & $0(0.0 \%)$ & $0(0.0 \%)$ & 4.2975 & .70291 \\
\hline $\begin{array}{l}\text { I can reorganize my task so that I get them satisfactorily } \\
\text { done on time }\end{array}$ & $56(46.3 \%)$ & $46(38.0 \%)$ & $19(15.7 \%)$ & $0(0.0 \%)$ & $0(0.0 \%)$ & 4.3058 & .72850 \\
\hline $\begin{array}{l}\text { I value the flexible working schedule more than seeking } \\
\text { a new role in another firm (should the right opportunity } \\
\text { present itself. }\end{array}$ & $47(38.8 \%)$ & $48(39.7 \%)$ & $21(17.4 \%)$ & $5(4.1 \%)$ & $0(0.0 \%)$ & 4.1322 & .84599 \\
\hline $\begin{array}{l}\text { Expanding the number of hours of giving out services is } \\
\text { done through work shift hence influences the number of } \\
\text { hours an employee can perform his/her tasks }\end{array}$ & $37(30.6 \%)$ & $67(55.4 \%)$ & $17(14.0 \%)$ & $0(0.0 \%)$ & $0(0.0 \%)$ & 4.1653 & .64996 \\
\hline $\begin{array}{l}\text { Job sharing helps in reducing absenteeism in as per } \\
\text { number of days an employee attends work }\end{array}$ & $55(45.5 \%)$ & $40(33.1 \%)$ & $26(21.4 \%)$ & $0(0.0 \%)$ & $0(0.0 \%)$ & 4.2397 & .78554 \\
\hline $\begin{array}{l}\text { Job sharing positively affects performance in terms of } \\
\text { Productivity }\end{array}$ & $46(38.0 \%)$ & $60(49.6 \%)$ & $15(12.4 \%)$ & $0(0.0 \%)$ & $0(0.0 \%)$ & 4.2562 & .66494 \\
\hline $\begin{array}{l}\text { Temporary contracts attracts employees with new skills } \\
\text { which influences ability of employees in the organization }\end{array}$ & $40(33.1 \%)$ & $67(55.4 \%)$ & $13(10.7 \%)$ & $1(0.8 \%)$ & $0(0.0 \%)$ & 4.2066 & .65723 \\
\hline $\begin{array}{l}\text { I am always motivated by the flexible time arrangement } \\
\text { that my Co-operative offers }\end{array}$ & $67(55.4 \%)$ & $39(32.2 \%)$ & $15(12.4 \%)$ & $0(0.0 \%)$ & $0(0.0 \%)$ & 4.4298 & .70506 \\
\hline
\end{tabular}

84 This work is licensed under a Creative Commons Attribution 4.0 International License. 
According to the finding, 55(45.5\%) of respondents strongly agreed, 40(33.1\%) agreed, and 26(21.4\%) were neutral that job sharing helped in reducing absenteeism as per the number of days an employee attends work. A mean of 4.2397 confirms that job sharing was indeed helpful in lowing absenteeism. The same opinions were held across different respondents from co-operative societies $(S D=$ 0.78554).

The response on whether job sharing positively affects performance in terms of productivity revealed that $46(38.0 \%)$ strongly agreed, 60(49.6\%) agreed and 15(12.4\%) were not sure. A mean of 4.2562 further indicated that job sharing satisfactorily had a positive influence on the production of the co-operative. A low standard deviation of 0.66494 revealed low variation in opinion across the co-operatives.

Temporary contracts were found to adequately attracts employees with new skills, which influences the ability of employees in the organisation $(M=4.2066)$. This is after $40(33.1 \%)$ strongly agreed, 67(55.4\%) agreed, 13(10.7\%) not sure, and $1(0.8 \%)$ disagreed with the same opinion. Its variation was considerably low at a standard deviation of 0.65723 , implying similar opinions among respondents. The respondents were always agreeably motivated by the flexible time arrangement that their Co-operative offers $(M=$ 4.4298). This was because $67(55.4 \%)$ strongly agreed, 39(32.2\%) agreed, and 15(12.4\%) were not sure. While a standard deviation of 0.70506 showed that opinion was homogeneous across the respondents. Dousin et al. (2019) found similar results that effective work-life equilibrium assisted job performance and productivity. Work arrangement leads to employee motivation, retention, and attraction to increase employee productivity. John (2017) added that part-time arrangements improved the performance and productivity of an organisation.

\section{Employee Performance}

Table 2 revealed that flexible work arrangements increased employee satisfaction in the organisation ( $M=4.6198)$ where $82(67.8 \%)$ of the respondents strongly agreed, 32(26.4\%) agreed, and 7(5.8\%) were not sure about the statement. A standard deviation of 0.59521 indicated low variation in opinion on satisfaction level among the respondents. The customers were able to meet their needs by the end of the day because of flexible work arrangements $(M=4.5372)$. After $65(53.7 \%)$ strongly agreed and 56(46.3\%) agreed on work arrangements. A standard deviation of 0.50069 revealed low variation in customer satisfaction across the co-operative. According to the results, creativity and innovation had been as a result of flexible work arrangements $(M=4.3636)$. Whereby there were 56(46.3\%) respondents who were strongly agreed, 53(43.8\%) agreed, and 12(9.9\%) were not sure. Its variations in opinions were low to some extent $(S D=0.65828)$. 


\section{Table 2: Descriptive Statistics on Employee Performance}

\begin{tabular}{|c|c|c|c|c|c|c|c|}
\hline & $\mathbf{S A}$ & $\mathbf{A}$ & $\mathbf{N}$ & D & SD & Mean & Std. Dev \\
\hline $\begin{array}{l}\text { Due to flexible work arrangement, am satisfied to work for the } \\
\text { organization }\end{array}$ & $82(67.8 \%)$ & $32(26.4 \%)$ & $7(5.8 \%)$ & $0(0.0 \%)$ & $0(0.0 \%)$ & 4.6198 & .59521 \\
\hline $\begin{array}{l}\text { I am able to meet customers' needs by the end of the day } \\
\text { because of flexible work arrangements }\end{array}$ & $65(53.7 \%)$ & $56(46.3 \%)$ & $0(0.0 \%)$ & $0(0.0 \%)$ & $0(0.0 \%)$ & 4.5372 & .50069 \\
\hline $\begin{array}{l}\text { My creativity and innovation has been a result of flexible work } \\
\text { arrangement. }\end{array}$ & $56(46.3 \%)$ & $53(43.8 \%)$ & $12(9.9 \%)$ & $0(0.0 \%)$ & $0(0.0 \%)$ & 4.3636 & .65828 \\
\hline $\begin{array}{l}\text { My manager allows me time to attend to family and personal } \\
\text { concerns hence am able to attain my targets. }\end{array}$ & $34(28.1 \%)$ & $81(66.9 \%)$ & $6(5.0 \%)$ & $0(0.0 \%)$ & $0(0.0 \%)$ & 4.2314 & .52853 \\
\hline $\begin{array}{l}\text { In my opinion, family engagements has positively affected my } \\
\text { performance at work. }\end{array}$ & $47(38.8 \%)$ & $62(51.2 \%)$ & $12(9.9 \%)$ & $0(0.0 \%)$ & $0(0.0 \%)$ & 4.2893 & .63820 \\
\hline $\begin{array}{l}\text { Am able to serve customers with ease because of provisions of } \\
\text { good leave policy. }\end{array}$ & $48(39.7 \%)$ & $60(49.6 \%)$ & $13(9.9 \%)$ & $0(0.0 \%)$ & $0(0.0 \%)$ & 4.2893 & .65113 \\
\hline $\begin{array}{l}\text { I get minimal complaints from customers because am able to } \\
\text { balance work and other aspects of life. }\end{array}$ & $47(38.8 \%)$ & $62(51.2 \%)$ & $12(9.9 \%)$ & $0(0.0 \%)$ & $0(0.0 \%)$ & 4.2893 & .63820 \\
\hline $\begin{array}{l}\text { Minimal complaints have been received because employees } \\
\text { have time off to attend to critical family issues. }\end{array}$ & $45(37.2 \%)$ & $67(55.4 \%)$ & $9(7.4 \%)$ & $0(0.0 \%)$ & $0(0.0 \%)$ & 4.2975 & .60062 \\
\hline $\begin{array}{l}\text { Customer complaints has drastically reduced because of } \\
\text { timeliness in customer service. }\end{array}$ & $73(60.3 \%)$ & $34(28.1 \%)$ & $14(11.6 \%)$ & $0(0.0 \%)$ & $0(0.0 \%)$ & 4.4876 & .69661 \\
\hline
\end{tabular}

86 This work is licensed under a Creative Commons Attribution 4.0 International License. 
The results revealed that $34(28.1 \%)$ of the respondents strongly agreed, $81(66.9 \%)$ agreed, and $6(5.0 \%)$ were not sure that managers allowed employees time to attend to family and personal concerns. A mean result of 4.2314 indicated that the managers gave employees time for family and personal concerns, which enabled them to attain their targets. A low variation with a standard deviation of 0.52853 reveals a homogenous opinion across the respondents. According to the results, family engagements has positively affected employee performance at work $(M=4.2893)$. Where $47(38.8 \%)$ of the respondents strongly agreed, 62(51.2\%) agreed, and 12(9.9\%) were not sure. The variation was low, which implies most of the respondents were in agreement $(S D=0.63820)$.

Findings indicated $48(39.7 \%)$ of the respondents strongly agreed, 60(49.6\%) agreed, and 13(9.9\%) were not sure whether employees were able to serve customers with ease because of provisions of a good leave policy. Hence, a mean of 4.2893 indicated that the employees satisfactorily provided good customer service based on a good leave policy. A standard deviation of 0.65113 revealed low variation in opinion on good leave policy.

Table 3: Correlation Analysis Results
The employee got minimal complaints from customers because the employer was able to balance work and other aspects of life $(M=4.2893)$. Whereby $47(38.8 \%)$ of the respondents strongly agree, 62(51.2\%) agree, and 12(9.9\%) were not sure. A low standard deviation of 0.63820 indicated a homogenous opinion across the employees. The results indicated $45(37.2 \%)$ of the respondents strongly agreed, 67(55.4\%) agreed, and 9(7.4\%) were not sure that minimal complaints had been received because employees had time off to attend to critical family issues. This implied that minimal complaints were based on employees having sufficient time for family issues $(M=4.2975)$. A standard deviation of 0.60062 indicated homogenous opinion among the respondents.

A mean of 4.4876 indicated that customer complaints had drastically reduced because of timeliness in customer service; where $73(60.3 \%$ ) of the respondents strongly agreed, 34(28.1\%) agreed, and $14(11.6 \%)$ were neutral on customer service timelines. A standard deviation of 0.69661 revealed low variation in opinion among the co-operatives.

The summary of correlation analysis is presented in Table 3.

\begin{tabular}{lll}
\hline & & Employee Performance \\
\hline \multirow{3}{*}{ Flexible Work Arrangement } & Pearson Correlation & $.801^{* *}$ \\
& Sig. (2-tailed) & .000 \\
& $\mathrm{~N}$ & 121 \\
\hline
\end{tabular}

Table 3 indicated that flexible work arrangements had a strong significant positive relationship with employee performance $(R=0.801, \mathrm{P}<0.05)$. Dousin et al. (2019) concurred that flexible work arrangements had positive significance on employee job performance.

\section{CONCLUSIONS}

The study concluded that flexible work arrangements had a significant positive relationship with employee performance in agricultural cooperative societies within Kericho County. Agricultural co-operatives were able to do this by offering flexible work arrangements. This included flexible work scheduling, expanded working hours to allow shift work, job sharing and adoption of temporary contracts to attract new abilities and skills. Flexible time arrangement motivated the cooperative to work smoothly.

\section{Recommendations}

87 | This work is licensed under a Creative Commons Attribution 4.0 International License. 
The study recommended that the organisation should adopt flexible work arrangements through investing in ICT infrastructure. Therefore, information communication and technology should be used through the adoption of the internet, mobile and electronic platforms that can be used any place. Flexible work arrangements can be done to fit different employees if well monitored and scheduled using a computerised system to ensure continuous productivity. This will enable employees to work efficiently and ensure that the organisation run smoothly.

\section{REFERENCES}

Dousin, O., Collins, N., \& Kaur Kler, B. (2019). Work-life balance, employee job performance and satisfaction among doctors and nurses in Malaysia. International Journal of Human Resource Studies, 9(4), 306-319.

Felstead, A., \& Henseke, G. (2017). Assessing the growth of remote working and its consequences for effort, well-being and work-life balance. New Technology, Work and Employment, 32(3), 195212.

Frischman, B. M., \& Lemley, M. A. (2007). Spillovers. Colum. L. Rev., 107, 257.

Haar, J., \& Brougham, D. (2020). Work antecedents and consequences of work-life balance: A two sample study within New Zealand. The International Journal of Human Resource Management, 1-24.

ILO (2010). International Labour Organization Report 2010.

John, W. (2017). Flexible working hours and organisational productivity: exploring the potential linkage. AIMA Journal of Management \& Research, 11(4/4), 1-7.

Kasau, M. G. (2017). Work-life balance and Employee Performance in the Ministry of
Finance and Economic Planning Kitui County Government, Kenya.

Mendis, M. D. V. S., \& Weerakkody, W. A. S. (2014). The Relationship between Work-life Balance and Employee Performance: With Reference to Telecommunication Industry of Sri Lanka. Kelaniya Journal of Human Resource Management, 8(2), 1-11.

Mulanya, C., \& Kagiri, A. (2018). Effect of Worklife Balance on Employee Performance in Constitutional Commissions in Kenya. The Strategic Journal of Business and Change Management, 5(4), 1448-1466.

Musleh Lafi Al-Maaitah, M. (2019). Organisational effectiveness in Banking sector in Jordan: a case study of Cairo Amman Bank. Doctoral dissertation, Aligarh Muslim University.

Sánchez-Hernández, M. I., González-López, Ó. R., Buenadicha-Mateos, M., \& Tato-Jiménez, J. L. (2019). Work-life balance in great companies and pending issues for engaging new generations at work. International journal of environmental research and public health, 16(24), 5122.

Sidin, S., Sambasivan, M., \& Ismail, I. (2010). Relationship between work-family conflict and quality of life: An investigation into the role of social support. Journal of Managerial Psychology, 25(1), 58-81.

Sirma, J. (2015). The Relationship between Worklife Balance Practices and Employee Performance: Case Study of UN Women Esaro. Doctoral dissertation. United States International University-Africa.

Talukder, A. M. H. (2019). Supervisor support and organisational commitment: the role of workfamily conflict, job satisfaction, and work-life balance. Journal of Employment Counseling, 56(3), 98-116.

88 This work is licensed under a Creative Commons Attribution 4.0 International License. 
East African Journal of Business and Economics, Volume 5, Issue 1, 2022

Article DOI: https://doi.org/10.37284/eajbe.5.1.557

Wilkinson, K., Tomlinson, J., \& Gardiner, J. (2018). The perceived fairness of work-life balance policies: A UK case study of solo-living managers and professionals without children. Human Resource Management Journal, 28(2), 325-339.

89 | This work is licensed under a Creative Commons Attribution 4.0 International License. 